\title{
BCL6 Rearrangement Indicates Poor Prognosis in Diffuse Large B-cell Lymphoma Patients: A Meta-analysis of Cohort Studies
}

\author{
Shu Li1,2†, Zhan Wang ${ }^{3 \dagger}$, Liming Lin ${ }^{1,2}$, Zhaoxing $\mathrm{Wu}^{1,2}$, Qingfeng $\mathrm{Yu}^{1,2}$, Feiqiong Gao', Jiawei Zhang1, Yang \\ $\mathrm{Xu}^{1 \mathrm{~W}}$ \\ 1. Department of Hematology, the Second Affiliated Hospital, Zhejiang University School of Medicine, Hangzhou 310009, China \\ 2. Cancer Institute (Key Laboratory of Cancer Prevention and Intervention, China National Ministry of Education), the Second Affiliated Hospital, Zhejiang \\ University School of Medicine, Hangzhou 310009, China \\ 3. Center for Orthopaedic Research, Orthopaedics Research Institute of Zhejiang University, Department of Orthopaedics, the Second Affiliated Hospital, \\ Zhejiang University School of Medicine, Hangzhou, 310009, China. \\ †Shu Li and Zhan Wang contributed equally to this work.
}

$\square$ Corresponding author: Yang Xu, PhD, MD, Professor, Department of Hematology, The Second Affiliated Hospital, Zhejiang University School of Medicine, Hangzhou 310009, China. Tel: 86-571-89713679; Fax: 86-571-87783655; E-mail: yxu@zju.edu.cn

(c) Ivyspring International Publisher. This is an open access article distributed under the terms of the Creative Commons Attribution (CC BY-NC) license (https:// creativecommons.org/licenses/by-nc/4.0/). See http://ivyspring.com/terms for full terms and conditions.

Received: 2018.02.26; Accepted: 2018.10.03; Published: 2019.01.01

\begin{abstract}
BCL6 (3q27) rearrangement is the most frequent chromosomal abnormality in diffuse large B-cell lymphoma (DLBCL). Previously, studies on the association between BCL6 rearrangement and DLBCL outcome remain controversial. Here we systematically reviewed literatures to identify the prognostic significance of BCL6 rearrangement in DLBCL. Meta-analytic methods are used to obtain pooled estimates of the association between BCL6 rearrangement and prognosis in DLBCL patients treated with different chemotherapy regimens. A total of 22 studies are enrolled in the cohort, involving 3037 patients. BCL6 rearrangement is verified to be negatively associated with overall survival (OS) $(H R=1.36, p=0.000)$, but not with progression-free survival (PFS). Moreover, the subgroup analyses show that BCL6 rearrangement is prognostic only in DLBCLs treated with rituximab-containing regimens.
\end{abstract}

Key words: BCL6; rearrangement; prognosis; diffuse large B-cell lymphoma; meta-analysis.

\section{Introduction}

Diffuse large B-cell lymphoma (DLBCL), which is the most frequent subtype of non-Hodgkin lymphoma (NHL), exhibits great biological heterogeneity and invasiveness $(1,2)$. Over the last decade, complete response (CR) and outcome in DLBCL patients have improved since rituximab (R) was added to cyclophosphamide, doxorubicin, vincristine, and prednisone (R-CHOP) (3). However, $\mathrm{R}-\mathrm{CHOP}$ is found to be inadequate in $30 \%$ to $40 \%$ of patients, resulting in primary refractory or relapsed DLBCL, better treatment strategies are needed. In addition, although the international prognostic index (IPI) has been commonly used for risk stratification of NHL (4), prognostic markers applicable primarily for
DLBCL are still lacking. Therefore, it is necessary and urgent to identify more prognostic markers for formulating the individualized regimens.

BCL6 is an oncogene that functions as a central regulator of germinal center development of B cells, and BCL6 expression is higher in the germinal center B-cell (GCB) subtpye than in the activated B-cell (ABC) subtype of DLBCL $(5,6)$. Among all types of chromosomal aberrations, BCL6 (3q27) rearrangement is the most common chromosomal abnormality, accounting for nearly half of the patients (7). Previous studies on the association between BCL6 rearrangement and survival of DLBCL patients had showed conflicting results (8-10). Moreover, Sehn et 
al. found that the predictive significance of some prognostic factors might change with the usage of rituximab (1). Therefore, further investigation is needed to reevaluate the relationship between BCL6 rearrangement and DLBCL.

In this study, we found that BCL6 rearrangement is significantly associated with poor outcome and linked with rituximab plus chemotherapy in a large cohort of DLBCL patients.

\section{Methods}

\section{Literature search and study selection}

A PubMed literature search updated through Augest 14, 2018, was mainly conducted to identify studies that compared BCL6 normal in DLBCL with BCL6 rearrangement and had information on disease risk and outcome. Specific search terms and all possible combinations were "BCL6", "LAZ3", "rearrangement", "translocation", "abnormalities" and "diffuse large B-cell lymphoma", "non-Hodgkin's lymphoma". Moreover, we searched PMC, Web of Science, and EMBASE databases to get a more comprehensive coverage and more updated information and examined the references to identify additional studies for inclusion. The latest study was chosen to avoid duplicate analysis when studies had overlapping population.

\section{Data extraction and quality assessment}

Four primary investigators (Shu Li, Zhan Wang, Liming Lin and Zhaoxing $\mathrm{Wu}$ ) independently conducted data extraction and quality assessment. Disagreements were appraised by another two reviewers (Qingfeng $\mathrm{Yu}$ and Feiqiong Gao). The following information was extracted from eligible studies: first author, year of publication, study region, characteristics of the study population, sample size (total cases, BCL6 rearrangement cases, BCL6 normal cases), outcome type, hazard ratio (HR), 95\% confidence interval (95\% CI) of overall survival (OS) or progression-free survival (PFS) and the clinical-pathological data. If the $\mathrm{HR}$ and the corresponding 95\% CI were not reported directly, data were extracted from the survival curve by utilizing Engauge Digitizer version 4.1 (http:// digitizer.sourceforge.net/). In addition, when the eligible studies did not present enough data, corresponding authors were contacted.

The quality of each eligible study was assessed according to the Newcastle-Ottawa Quality Assessment Scale (NOS). In the terms of the three components (selection, comparability, and exposure or outcome) of the NOS system, only studies with score of 4 or above were absorbed in our study.

\section{Statistical analysis}

For dichotomous variables, we aggregated the pooled HRs and the $95 \%$ CIs to predicate the impact of BCL6 rearrangement on both OS and PFS of DLBCL. The method was appropriate for subgroup analyses. We also calculated the odd ratios (ORs) and their corresponding $95 \% \mathrm{CI}$ to assess the correlation between BCL6 rearrangement and the clinical-pathological features of DLBCL. The inconsistency index $\left(\mathrm{I}^{2}\right)$ statistic and the $\mathrm{Q}$ statistic were used to test the statistical heterogeneity between the trials included in the meta-analysis. $p<0.1$ and $I^{2}>50 \%$ for the Q-test indicated substantial heterogeneity, a random-effect model was used. A fixed-effect model was used for secondary analysis when outcomes met fine heterogeneity $(p>0.1$; $\left.\mathrm{I}^{2} \leq 50 \%\right)$. Publication bias was evaluated via Egger's and Begg's test. All the data calculations were performed by STATA version 12.0 software (Stata Corporation, Collage Station, Texas, USA). A two-tailed p-value of less than 0.05 was considered statistically significant.

\section{Results}

\section{Literature search and study characteristics}

The flowchart of the article screening was shown in Figure 1. After repeatedly siftings abstracts, titles and full-text, a total of 22 literatures met the inclusion criteria and were included in this study (8-29). The characteristics of the eligible studies were shown in Table 1.

The twenty-two studies were published between 1997 and 2017, enrolling 3037 patients, the median age was 62 years, and the follow-up ranged from 1 to 187 months. Overall, 4 each were conducted in China and Japan, 2 in Turkey, 3 in America and England, and the remaining articles were from other 7 different countries. Of the 22 studies included, 22 provided the HR of OS and 7 provided the HR of PFS. Among studies related to BCL6 rearrangement and OS, 7 (10, $15,17,18,22,24,27)$ concluded that BCL6 rearrangement alone was a marker of poor prognosis, while others $(8,9,11-14,16,19-21,23,26,28,29)$ considered that the individual BCL6 rearrangement was not associated with the prognosis. In PFS related studies, only Niitsu et al (21) reported BCL6 rearrangement was associated with better outcome, other groups $(8,11,12,14,16,21)$ found no relevance between BCL6 rearrangement and PFS. The discrepancy was mainly focused on whether individual BCL6 rearrangement could serve as an indicator of poor prognosis.

Moreover, most studies provided the chemotherapy regimens, and Shustik et al 
investigated the relationship between BCL6 rearrangement and the outcome of DLBCL patients in groups with or without rituximab (17). Thus, how rituximab affects the prognostic value of BCL6 rearrangement was analyzed through calculating the pooled HRs in separate groups.

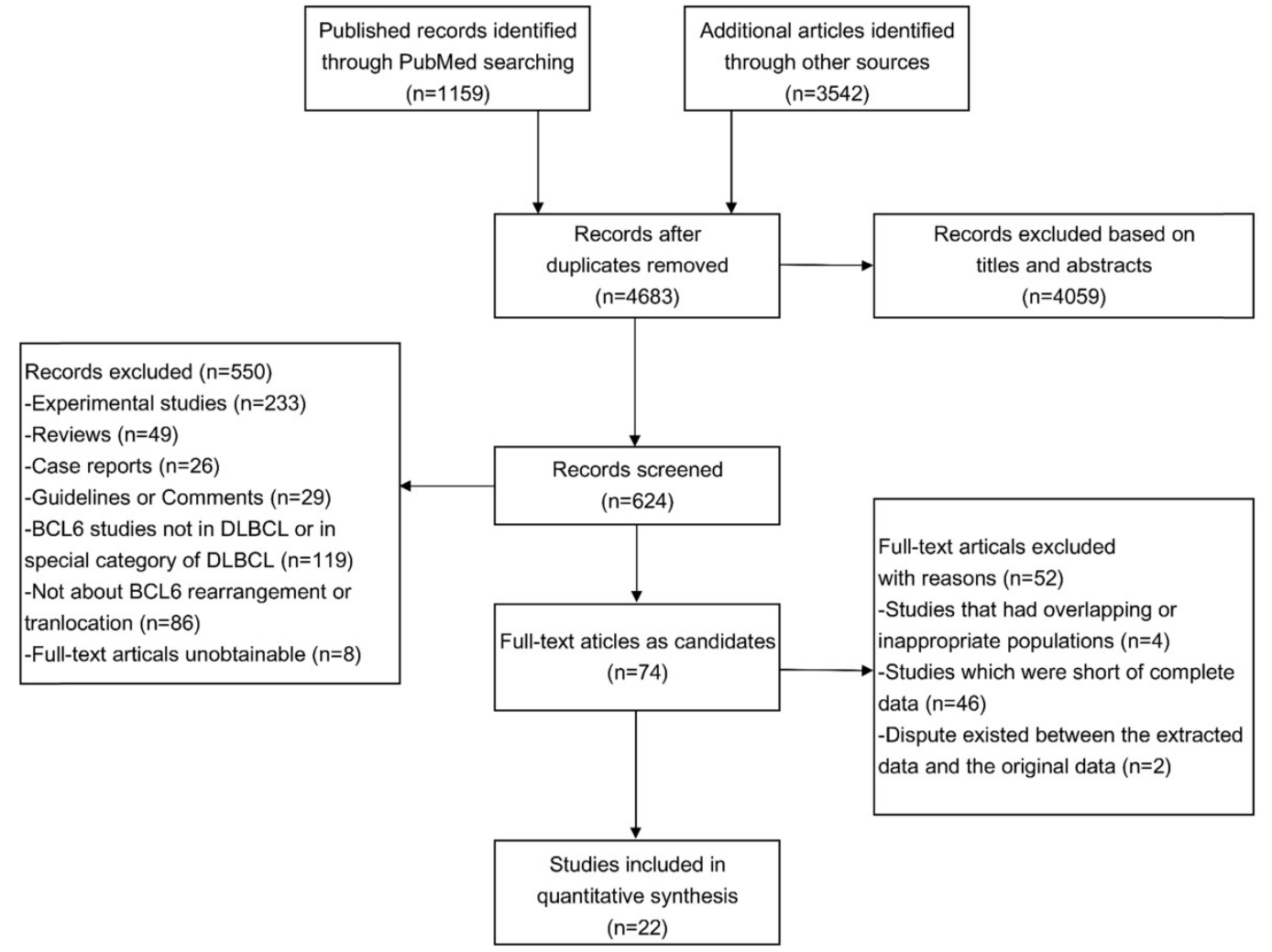

Figure 1. Flowchart of eligibles studies screening and the selection process.

Table 1. Characteristics summary of the 22 eligible studies in the meta-analysis of BCL6 rearrangement and DLBCL.

\begin{tabular}{|c|c|c|c|c|c|c|c|c|c|c|}
\hline Study & Year & Region & $\begin{array}{l}\text { Number of } \\
\text { patients } \\
(\mathrm{P} / \mathrm{N})\end{array}$ & $\begin{array}{l}\text { Median } \\
\text { age } \\
\text { (years) }\end{array}$ & $\begin{array}{l}\text { Median } \\
\text { follow-up } \\
\text { (months, } \\
\text { range) }\end{array}$ & $\begin{array}{l}\text { Detection } \\
\text { method }\end{array}$ & Main therapy regimen & Outcome & HR & $\begin{array}{l}\text { BCL6 } \\
\text { rearrangement } \\
\text { And OS }\end{array}$ \\
\hline Akay (13) & 2014 & Turkey & $44(20 / 24)$ & 56.6 & NR & FISH & NR & OS & Data-extrapped & Not relevant \\
\hline Ye (14) & 2015 & America & $\begin{array}{l}628 \\
(145 / 483)\end{array}$ & 64 & $58.9(1-187)$ & FISH & R-CHOP & OS, PFS & $\begin{array}{l}\text { Reported in } \\
\text { text }\end{array}$ & Not relevant \\
\hline $\begin{array}{l}\text { Akyurek } \\
(15)\end{array}$ & 2012 & Turkey & $\begin{array}{l}239 \\
(69 / 170)\end{array}$ & 59 & $26(2-96)$ & FISH & $\mathrm{R}-\mathrm{CHOP}$ & OS & Data-extrapped & Poor prognosis \\
\hline López (16) & 2016 & Spain & $\begin{array}{l}171 \\
(51 / 120)\end{array}$ & NR & NR & FISH & $\begin{array}{l}\mathrm{R}-\mathrm{CHOP} \text { and } \mathrm{R}-\mathrm{CHOP} \text {-like } \\
\text { regimens }\end{array}$ & OS, PFS & $\begin{array}{l}\text { Reported in } \\
\text { text }\end{array}$ & Not relevant \\
\hline Liang (27) & 2015 & China & $105(23 / 82)$ & 57 & $\begin{array}{l}66.1 \\
(0.5-127.9)\end{array}$ & FISH & CHOP or R-CHOP & OS & Data-extrapped & Poor prognosis \\
\hline Shustik (17) & 2009 & England & $\begin{array}{l}164 \\
(32 / 132)\end{array}$ & NR & $\begin{array}{l}38.4 \\
(3.6-104.4)\end{array}$ & FISH & $\mathrm{CHOP}$ or $\mathrm{R}-\mathrm{CHOP}$ & OS & Data-extrapped & Poor pronosis \\
\hline Gao (10) & 2014 & China & $65(39 / 26)$ & 59 & $\begin{array}{l}20.7 \\
(2.4-51.5)\end{array}$ & FISH & $\mathrm{CHOP}$ or $\mathrm{R}-\mathrm{CHOP}$ & OS & $\begin{array}{l}\text { Reported in } \\
\text { text }\end{array}$ & Poor prognosis \\
\hline Kramer (28) & 1998 & $\begin{array}{l}\text { the } \\
\text { Netherlands }\end{array}$ & $116(36 / 80)$ & NR & NR & $\begin{array}{l}\text { Southern } \\
\text { Blot }\end{array}$ & $\begin{array}{l}\text { Doxorubicin-containing } \\
\text { polychemotherapy with or } \\
\text { without radiotherapy or } \\
\text { radiotherapy alone }\end{array}$ & OS & Data-extrapped & Not relevant \\
\hline $\begin{array}{l}\text { Akasaka } \\
(24)\end{array}$ & 2000 & Japan & $\begin{array}{l}203 \\
(43 / 160)\end{array}$ & NR & NR & $\begin{array}{l}\text { Southern } \\
\text { Blot }\end{array}$ & $\begin{array}{l}\text { Combination chemotherapy with } \\
\text { doxorubicin or other } \\
\text { anthracyclines }\end{array}$ & OS & Data-extrapped & Poor prognosis \\
\hline $\begin{array}{l}\text { Bergman } \\
(18)\end{array}$ & 2009 & France & $69(21 / 48)$ & 67 & $80.4(1.2-96)$ & $\begin{array}{l}\text { Southern } \\
\text { Blot }\end{array}$ & $\mathrm{R}-\mathrm{CHOP}$ & OS & Data-extrapped & Poor prognosis \\
\hline Barrans (22) & 2001 & England & $111(28 / 83)$ & 66 & $\begin{array}{l}27.4 \\
(0.7-180.4)\end{array}$ & FISH & $\mathrm{CHOP}$ & OS & Data-extrapped & Poor prognosis \\
\hline Han (19) & 2013 & China & $59(22 / 37)$ & NR & NR & FISH & $\mathrm{CHOP}$ or $\mathrm{R}-\mathrm{CHOP}$ & OS & $\begin{array}{l}\text { Reported in } \\
\text { text }\end{array}$ & Not relevant \\
\hline Kawasaki & 2009 & Japan & 137 & 61 & $25(0.1-99)$ & Southern & NR & OS & Data-extrapped & Not relevant \\
\hline
\end{tabular}




\begin{tabular}{|c|c|c|c|c|c|c|c|c|c|c|}
\hline Study & Year & Region & $\begin{array}{l}\text { Number of } \\
\text { patients } \\
(\mathrm{P} / \mathrm{N})\end{array}$ & $\begin{array}{l}\text { Median } \\
\text { age } \\
\text { (years) }\end{array}$ & $\begin{array}{l}\text { Median } \\
\text { follow-up } \\
\text { (months, } \\
\text { range) }\end{array}$ & $\begin{array}{l}\text { Detection } \\
\text { method }\end{array}$ & Main therapy regimen & Outcome & HR & $\begin{array}{l}\text { BCL6 } \\
\text { rearrangement } \\
\text { And OS }\end{array}$ \\
\hline (20) & & & $(22 / 115)$ & & & Blot & & & & \\
\hline Chen (8) & 2001 & China & $59(10 / 49)$ & NR & NR & $\begin{array}{l}\text { Southern } \\
\text { Blot }\end{array}$ & Without any chemotherapy & OS, PFS & $\begin{array}{l}\text { Reported in } \\
\text { text }\end{array}$ & Not relevant \\
\hline $\begin{array}{l}\text { Pescarmona } \\
\text { (25) }\end{array}$ & 1997 & Italy & $41(10 / 31)$ & NR & 38.5 (NR) & $\begin{array}{l}\text { Southern } \\
\text { Blot }\end{array}$ & NR & OS & Data-extrapped & Not relevant \\
\hline $\begin{array}{l}\text { Kawamoto } \\
\text { (12) }\end{array}$ & 2016 & Japan & $61(8 / 53)$ & 62 & $40(2-127)$ & FISH & $\begin{array}{l}\mathrm{RCHOP} \text { or R-CHOP-like } \\
\text { regimens }\end{array}$ & OS, PFS & $\begin{array}{l}\text { Reported in } \\
\text { text }\end{array}$ & Not relevant \\
\hline Niitsu (21) & 2007 & Japan & $\begin{array}{l}186 \\
(43 / 143)\end{array}$ & 64 & $48(24-72)$ & FISH & CyclOBEAP regimens & OS, PFS & Data-extrapped & Not relevant \\
\hline $\begin{array}{l}\text { Jerkeman } \\
\text { (23) }\end{array}$ & 2002 & $\begin{array}{l}\text { Sweden and } \\
\text { Norway }\end{array}$ & 44 (NR) & 47 & 71 (NR) & $\begin{array}{l}\text { Southern } \\
\text { Blot }\end{array}$ & CHOP or MACOP-B & OS & Data-extrapped & Not relevant \\
\hline $\begin{array}{l}\text { Pedersen } \\
\text { (11) }\end{array}$ & 2017 & Denmark & $99(27 / 72)$ & NR & NR & FISH & R-CHOP or R-CHOEP & OS, PFS & $\begin{array}{l}\text { Reported in } \\
\text { text }\end{array}$ & Not relevant \\
\hline Horn (9) & 2013 & Germany & $\begin{array}{l}199 \\
(55 / 144)\end{array}$ & 68 & NR & FISH & R-CHOP or R-CHOEP & OS & $\begin{array}{l}\text { Reported in } \\
\text { text }\end{array}$ & Not relevant \\
\hline Vitolo (26) & 1998 & Italy & $71(11 / 60)$ & 66 & 36(NR) & $\begin{array}{l}\text { Southern } \\
\text { Blot }\end{array}$ & MACOP-B & OS & Data-extrapped & Not relevant \\
\hline Clipson (29) & 2015 & England & $\begin{array}{l}166 \\
(40 / 126)\end{array}$ & NR & NR & FISH & $\mathrm{R}-\mathrm{CHOP}$ & OS & Data-extrapped & Not relevant \\
\hline
\end{tabular}

Abbreviations: DLBCL, diffuse large B-cell lymphoma; HR, hazard ratio; OS, overall survival; PFS, progress-free survival; FISH, interphase fluorescent in situ hybridization; CHOP, cyclophosphamide, doxorubicin, vincristine, and prednisone; R-CHOP, rituximab, cyclophosphamide, doxorubicin, vincristine, and prednisone; CyclOBEAP, cyclophosphamide, vincristine, bleomycine, etoposide, doxorubicin, prednisone; MACOP-B, methotrexate, doxorubicin, cyclophosphamide, vincristine, prednisone, bleomycin; DA-EPOCH-R, etoposide, prednisone, vincristine, cyclophosphamide and doxorubicin and rituximab; CT, chemotherapy; CTC, corticotherapy; ACOPB, adriamycin, cyclophosphamide, vincristine, prednisone, bleomycin; RT, radiotherapy; ASCT, autologous stem cell transplantation; NR, not reported.

The association between BCL6 rearrangement and the survival of DLBCL patients

The pooled HRs of the OS provided in 22 articles was 1.36 (95\% CI: 1.08-1.71, p=0.000), accompanied with a statistical heterogeneity $\left(\mathrm{I}^{2}=57.4 \%, \mathrm{p}=0.000\right)$ (Figure 2A). A meta-analysis on 6 studies was performed to analyze the correlation between BCL6 rearrangement and PFS. The combined HR for PFS was 0.89 (95\% CI: 0.72-1.11, $\mathrm{p}=0.573)$ with a fine heterogeneity $\left(\mathrm{I}^{2}=14.0 \%, \mathrm{p}=0.325\right)$ (Figure $\left.2 \mathrm{~B}\right)$. The results demonstrated that BCL6 rearrangement was negatively associated with OS, but no PFS and BCL6 rearrangement may be an independent prognostic factor in DLBCL.

\section{The subgroup and sensitivity analyses}

Subgroup analysis of OS was performed according to publication era, study location, number of patients, statistical approach and test methods. The results revealed a significant negative association between BCL6 rearrangement and OS was exhibited in all strata (Table 2). Additionally, to define the role of rituximab in the association between BCL6 rearrangement and OS, subgroups with chemotherapy regimens were also evaluated for DLBCL. The pooled HRs for DLBCL with rituximab treatment was 1.39 (95\% CI: 1.03-1.87, p=0.033), while for DLBCL without rituximab was 1.18 (95\% CI: 0.73-1.90, $\mathrm{p}=0.498$ ) (Figure 3; Table 2).

The result of sensitivity analysis of OS showed that the gathered HR ranged from 1.31 (95\% CI: 1.05-1.63) of the study of Gao et al. (10) to 1.44 (95\% CI: 1.16-1.78) of the study of Horn et al. (9). It suggested that the negative association between BCL6 rearrangement and prognosis of DLBCL patients existed no matter which study was excluded (Figure $4)$.

\section{Association between BCL6 rearrangement and clinico-pathological characteristics of DLBCL}

Clinical-pathological analysis of OS was performed according to the common parameters, such as tumor stage, immunophenotypes of DLBCL, IPI score, serums LDH. Six studies were chosen to assess the association between BCL6 rearrangement and DLBCL immunophenotype. The combined OR was 0.454 (95\% CI: 0.292-0.704, $\mathrm{p}=0.000$ ), which indicated that BCL6 rearrangement was correlated with differentiation of DLBCL. Correlation between BCL6 rearrangement and serum LDH was also evaluated in eight studies. The pooled OR was 2.188 (95\% CI: 1.667-2.874, $p=0.000)$, suggesting that BCL6 rearrangement was superior to be associated with elevated serum LDH. BCL6 rearrangement was likely to accompany with high IPI score, which was an established prognostic factor (1) $(\mathrm{HR}=1.215,95 \% \mathrm{CI}$ : 1.031-1.433, $\mathrm{p}=0.042)$. However, there was no significant association between BCL6 rearrangement and other parameters, particularly for BCL6 expression. The pooled OR was shown in Table 3.

\section{Publication bias}

Begg's test showed no potential publication bias for BCL6 rearrangement with regard to OS, PFS and the clinico-pathological features of DLBCL. The funnel plots for the OS (Figure 5A) and PFS (Figure $5 B)$ were shown in our meta-analysis. 
A

Overall survival

Study ID

rBCL-6 vs. nBCL-6

Akay (2014)

Ye (2015)

Akyurek (2012)

Lopez (2016)

Liang (2015)

Shustik (2009)

Gao (2014)

Kramer (1998)

Akasaka (2000)

Bergman (2009)

Barrans (2001)

Han (2013)

Kawasaki (2009)

Chen (2001)

Pescarmona (1997)

Kawamoto (2016)

Niitsu (2007)

Jerkeman (2002)

Pedersen (2017)

Horn (2013)

Vitolo (1998)

Clipson (2015)

Overall (I-squared $=57.4 \%, p=0.000$ )

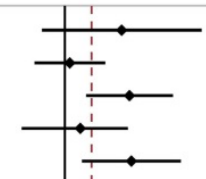

$\mathrm{HR}(95 \% \mathrm{Cl}) \quad$ Weight \%

NOTE: Weights are from random effects analysi\$

$\begin{array}{llll}1 & 1 & 1 \\ . & 1 & 1.5\end{array}$

B

Progression-free survival

\begin{tabular}{|c|c|c|c|}
\hline Study ID & rBCL-6 vs. nBCL-6 & $\mathrm{HR}(95 \% \mathrm{Cl})$ & Weight $\%$ \\
\hline Lopez (2016) & & $1.00(0.60,1.90)$ & 15.34 \\
\hline Ye (2015) & & $1.13(0.77,1.66)$ & 34.54 \\
\hline Chen (2001) & & $0.60(0.28,1.31)$ & 8.37 \\
\hline Kawamoto (2016) & & $0.74(0.22,2.47)$ & 3.49 \\
\hline Niitsu (2007) & & $0.65(0.39,1.00)$ & 22.49 \\
\hline Pedersen (2017) & & $1.30(0.77,2.40)$ & 15.77 \\
\hline Overall (I-squared $=14.0 \%, p=0.325)$ & & $0.94(0.75,1.17)$ & 100.00 \\
\hline
\end{tabular}

Figure 2. Forest plot of Hazard ratios for BCL-6 rearrangement and overall survival (A) or progress-free survival (B) of DLBCL. $r B C L-6, B C L-6$ rearrangement; $\mathrm{nBCL}-6, \mathrm{BCL}-6$ normal; $\mathrm{HR}$, hazard ratio; $95 \% \mathrm{Cl}, 95 \%$ confidence interval.

Table 2. Subgroup analysis for the prognostic values of BCL-6 rearrangement with OS in DLBCL patients.

\begin{tabular}{|c|c|c|c|c|c|c|}
\hline \multirow[t]{2}{*}{ Stratifies endpoints } & \multirow[t]{2}{*}{ Number of Studies } & \multirow[t]{2}{*}{ Number of patients } & \multirow[t]{2}{*}{ Pooled HR (95\% CI) } & \multirow[t]{2}{*}{ P value } & \multicolumn{2}{|c|}{ Heterogeneity } \\
\hline & & & & & $\mathbf{I}^{2}$ & P value \\
\hline \multicolumn{7}{|l|}{ Study location } \\
\hline Europe and America & 14 & 2162 & $1.371(1.048-1.794)$ & 0.021 & $57.4 \%$ & 0.000 \\
\hline Asia & 8 & 875 & $1.338(0.843-2.124)$ & 0.217 & $66.2 \%$ & 0.004 \\
\hline \multicolumn{7}{|l|}{ Number of patients } \\
\hline$\geq 100$ & 9 & 1851 & $1.213(1.018-1.444)$ & 0.031 & $69.8 \%$ & 0.001 \\
\hline$<100$ & 13 & 1186 & $1.682(1.336-2.571)$ & 0.000 & $33.1 \%$ & 0.117 \\
\hline \multicolumn{7}{|l|}{ Test method } \\
\hline FISH & 15 & 2366 & 1.437 (1.219-1.731) & 0.001 & $60.7 \%$ & 0.000 \\
\hline Southern Blot & 7 & 671 & $1.205(0.928-1.562)$ & 0.054 & $51.6 \%$ & 0.161 \\
\hline \multicolumn{7}{|c|}{ Chemotherapy regimens } \\
\hline With rituximab & 10 & 1837 & $1.387(1.026-1.874)$ & 0.033 & $53.0 \%$ & 0.024 \\
\hline Without rituximab & 6 & 731 & $1.179(0.732-1.900)$ & 0.498 & $67.4 \%$ & 0.009 \\
\hline
\end{tabular}

Abbreviations: OS, overall survival; DLBCL, diffuse large B-cell lymphoms; HR, hazard ratio; 95\% CI, 95\% confidence interval. 


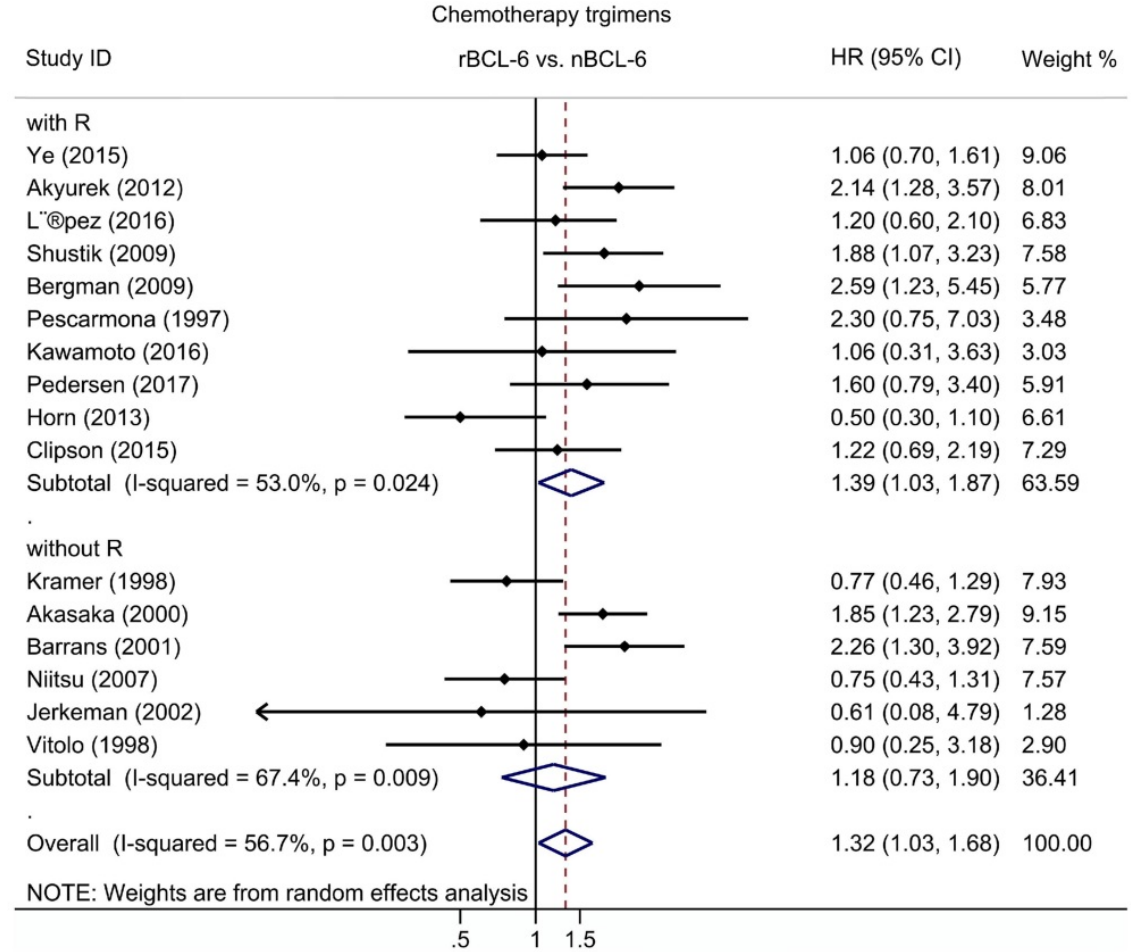

Figure 3. The hazard ratio of $B C L-6$ rearrangement associated with the overall survival of DLBCL with and without rituximab treatment. $r B C L-6, B C L-6$ rearrangement; $\mathrm{nBCL}-6, \mathrm{BCL}-6$ normal; $\mathrm{HR}$, hazard ratio; $95 \% \mathrm{Cl}, 95 \%$ confidence interval.

A

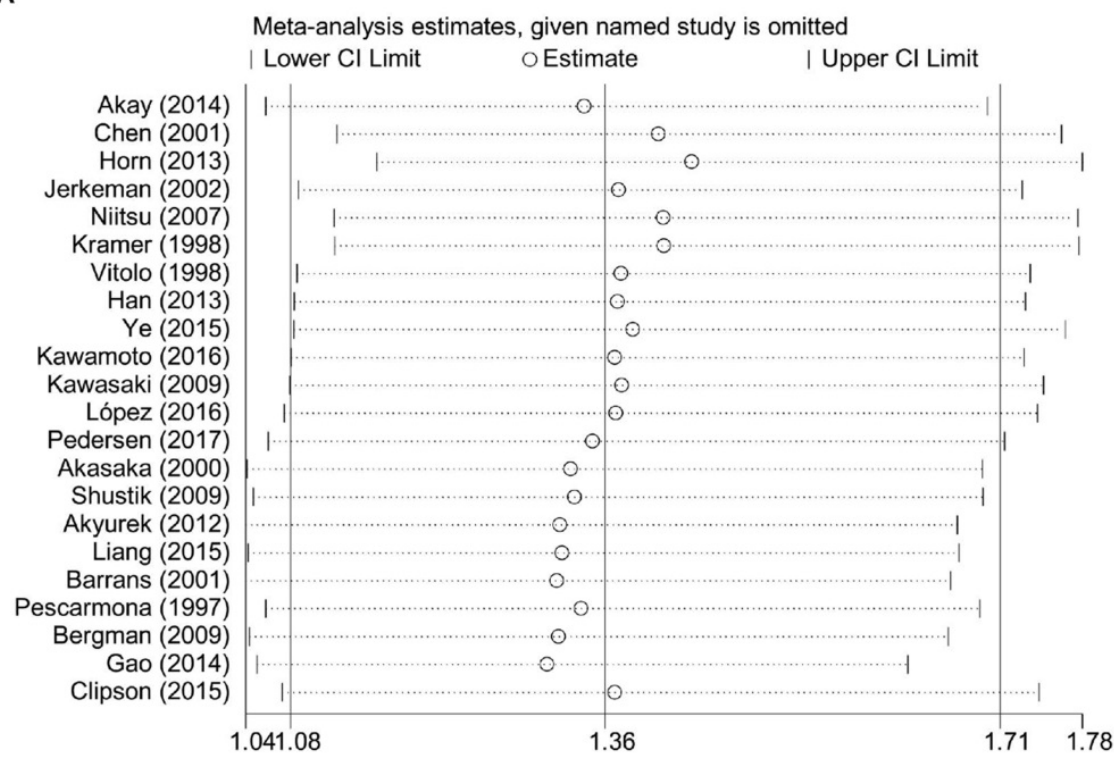

B

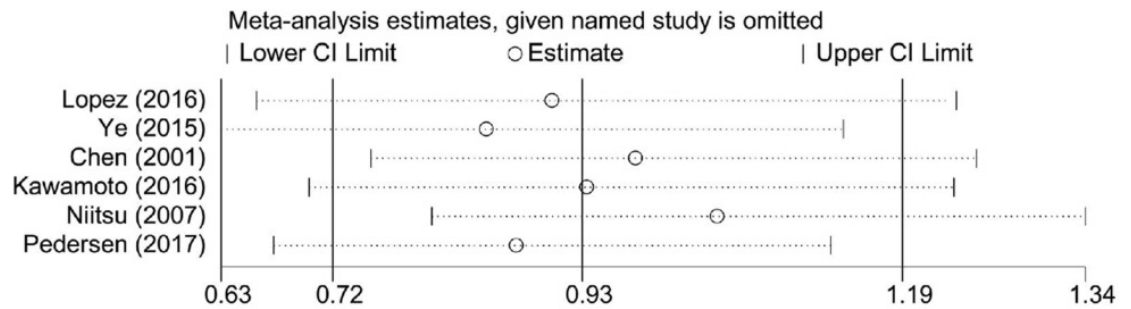

Figure 4. Sensitivity analysis for the meta-analysis of overall survival (A) and progress-free survival (B) in all patients with DLBCL. Cl, confidence interval. 
Table 3. Summary estimates of the OR for the associations of BCL-6 rearrangement and clinical-pathological features of DLBCL.

\begin{tabular}{|c|c|c|c|c|c|c|}
\hline \multirow[t]{2}{*}{ Clinicopathological features } & \multirow{2}{*}{$\begin{array}{l}\text { Number of } \\
\text { studies }\end{array}$} & \multirow{2}{*}{$\begin{array}{l}\text { Number of } \\
\text { patients }\end{array}$} & \multirow[t]{2}{*}{ Pooled OR (95\% CI) } & \multirow[t]{2}{*}{ Pvalue } & \multicolumn{2}{|c|}{ Heterogeneity } \\
\hline & & & & & $\mathbf{I}^{2}$ & Pvalue \\
\hline Age (<60 vs. $\geq 60)$ & 5 & 485 & $0.943(0.771-1.153)$ & 0.566 & $0.00 \%$ & 0.595 \\
\hline Gender (Female vs. Male) & 8 & 838 & $0.897(0.746-1.079)$ & 0.248 & $0.00 \%$ & 0.631 \\
\hline Tumor stage (I-II vs. III-IV) & 10 & 1083 & $0.916(0.773-1.086)$ & 0.313 & $0.00 \%$ & 0.744 \\
\hline Type (GCB vs. ABC) & 6 & 1337 & $0.454(0.292-0.704)$ & 0.000 & $51.70 \%$ & 0.066 \\
\hline IPI score (3-5 vs.0-2) & 6 & 696 & $1.215(1.031-1.433)$ & 0.042 & $15.40 \%$ & 0.315 \\
\hline Primary site (Nodal vs. Extranodal) & 4 & 570 & $1.006(0.863-1.174)$ & 0.935 & $64.00 \%$ & 0.039 \\
\hline Extranodal site (No vs. Yes) & 5 & 445 & $1.012(0.891-1.150)$ & 0.851 & $1.90 \%$ & 0.396 \\
\hline BCL2 expression (+ vs. -) & 4 & 463 & $1.071(0.901-1.272)$ & 0.437 & $60.70 \%$ & 0.054 \\
\hline BCL6 expression (+ vs. -) & 3 & 452 & $1.015(0.875-1.179)$ & 0.841 & $63.50 \%$ & 0.065 \\
\hline Serous LDH (Elevated vs. Normal) & 8 & 739 & $2.188(1.667-2.874)$ & 0.000 & $74.30 \%$ & 0.000 \\
\hline Bone marrow involvement (+ vs. -) & 4 & 436 & $0.795(0.542-1.168)$ & 0.243 & $0.00 \%$ & 0.565 \\
\hline
\end{tabular}
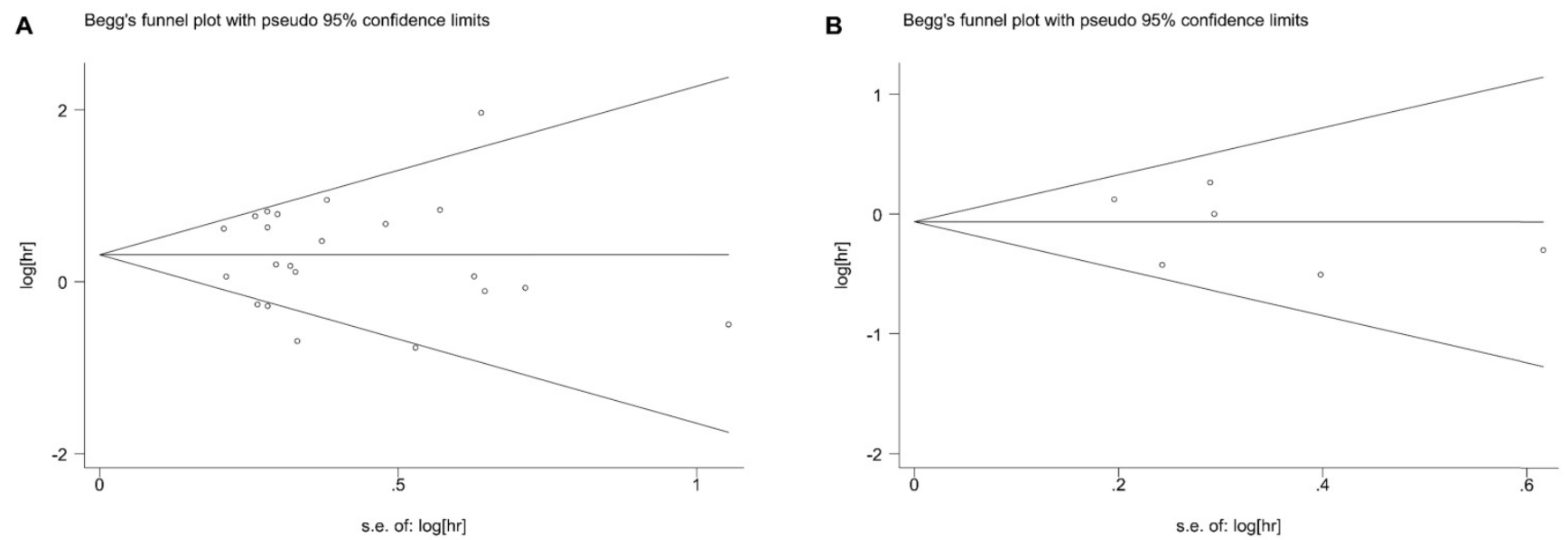

Figure 5. Begg's funnel plot of BCL-6 rearrangement and overall survival (A) or progress-free survival (B) of DLBCL for the assessment of publication bias. Each point represents a separate study for the indicated association. DLBCL, diffuse large B-cell lymphoma.

\section{Discussion}

BCL6, first identified and named in 1993 by Baron et al. (31), is a transcription regulator that plays an important role in lymphomagenesis (31). Moreover, among all types of aberrations in DLBCL, BCL6 (3q27) rearrangement is the most common (7, 31). Currently, the relationship between BCL6 rearrangement and prognosis of patients with DLBCL remains controversial. Hence, we performed the first meta-analysis to to explore the correlation between BCL6 rearrangement and survival outcomes in DLBCL.

Our study collectively summarized all available evidence from 22 prognosis-related studies and had sufficient power for association studies. We found that BCL6 rearrangement was associated with worse OS in patients with DLBCL $(\mathrm{HR}=1.36,95 \% \mathrm{CI}$ : $1.08-1.71, p=0.000)$, but no PFS (HR=0.94, 95\% CI: $0.75-1.17, \mathrm{p}=0.573)$. Sensitivity analysis suggested that the association between BCL6 rearrangement and prognosis of DLBCL was stable and authentic. Additionally, subgroup analyses demonstrated BCL6 rearrangement was an adverse prognostic factor, regardless of human races, detection methods and the number of patients enrolled, i.e. BCL6 is an independent prognostic factor for DLBCL.

Since many validated prognostic factors losing statistical significance along with the usage of rituximab was reported in previous studies $(1,32)$, we also analyzed the effect of rituximab on the prognostic significance of BCL6 rearrangement in DLBCL. The prognostic value of BCL6 rearrangement in DLBCL became significant following rituximab treatment (HR=1.39; 95\% CI: 1.03-1.87, $\mathrm{p}=0.033$ ), while for DLBCL without rituximab, BCL6 rearrangement was not related to OS rates (HR=1.18, 95\% CI: 0.73-1.90, $\mathrm{p}=0.498$ ). As to clinico-pathological parameters analysis, BCL6 rearrangement was found to express more frequently in tumors with high IPI scores (score 3-5), elevated serum LDH and ABC-immunophenotype. It should be noted that no publication bias was found in this meta-analysis.

Though our study investigated the prognostic value of BCL6 rearrangement in DLBCL, some potential limitations still exist and the results should be interpreted with caution. First, the individual primary data from the included studies was not available, these data extracted from survival curves might be less reliable than those directly reported in 
the texts. Second, the risk estimates used in pooling might not be fully adjusted for, since some covariates did not always exist in the included studies. Numerical results might appear deviation in our findings. Third, we were unable to evaluate the relationship between BCL6 rearrangement and specific treatment regimens due to the limited data.

In conclusion, this meta-analysis supports the significant correlation between BCL6 rearrangement and adverse survival outcome. In DLBCL, BCL6 rearrangement has the prognostic value only when rituximab was included in chemotherapy. High IPI score, $\mathrm{ABC}$ type and elevated $\mathrm{ABC}$ type and elevated serum LDH are likely to accompanied by BCL6 rearrangement. Further adequately designed prospective studies are still needed to verify our results.

\section{Abbreviations}

DLBCL: diffuse large B-cell lymphoma; NHL: non-Hodgkin lymphoma; CR: complete response; R: rituximab; CHOP: cyclophosphamide, doxorubicin, vincristine, and prednisone; IPI: international prognostic index; GCB: germinal center B-cell-like; ABC: activated center B-cell-like; HR: hazard ratio; CI: confidence interval; NOS: Newcastle-Ottawa Scale; OS: overall survival; PFS: progress-free survival; OR: odds ratio; $\mathrm{I}^{2}$ : inconsistency index; LDH: lactate dehydrogenase.

\section{Acknowledgements}

This study was supported by National Natural Science Foundation of China (No. 81572920), Natural Science Foundation of Zhejiang Province of China (No.LY15H160038) and National Basic Research Program of China (No.2013CB911303).

\section{Competing Interests}

The authors have declared that no competing interest exists.

\section{References}

1. Sehn LH. Paramount prognostic factors that guide therapeutic strategies in diffuse large B-cell lymphoma. Hematology. 2002;2002:402-9.

2. Wang W, Hu S, Lu X, et al. Triple-hit B-cell Lymphoma With MYC, BCL2, and BCL6 Translocations/Rearrangements. Am J Surg Pathol. 2015;39(8):1132-9.

3. Coiffier B, Lepage E, Briere J, et al. CHOP chemotherapy plus rituximab with CHOP aline in elderly patients with diffuse large B-cell lymphoma. New Engl J Med. 2002;346:235-42.

4. Perry AM, Mitrovic Z, Chan WC. Biological Prognostic Markers in Diffuse Large B-Cell Lymphoma. Cancer Control. 2012;19(3):214-26.

5. Lossos C, Bayraktar S, Weinzierl E, et al. LMO2 and BCL6 are associated with improved survival in primary central nervous system lymphoma. Brit J Haematol. 2014;165(5):640-8:640-8.

6. Green MR, Dueñas CV, Camarero IR, et al. Transient expression of Bcl6 is sufficient for oncogenic function and induction of mature B-cell lymphoma. Nat Commun. 2014; 5:3904-32.

7. Jarosova1 M, Kriegova E, Schneiderova $P$, et al. A Novel Non-Immunoglobulin (non-Ig)/BCL6 Translocation in Diffuse Large
B-Cell Lymphoma Involving Chromosome 10q11.21 Loci and Review on Clinical Consequences of BCL6 Rearrangements. Pathol Oncol Res. 2015;22(2):233-43.

8. Chen PM, Yang MH, Yu IT, et al. Low incidence of BCL-6 gene alterations fordiffuse large B-cell lymphomas in Taiwan Chinese. Cancer. 2002;94(10):2635-44.

9. Horn H, Ziepert M, Becher C, et al. MYC status in concert with BCL2 and BCL6 expression predicts outcome in diffuse large B-cell lymphoma. Blood. 2013;121(12):2253-63.

10. Gao P, Li Q, Wang Z, et al. Significance of BCL6, MYC, P53 genes abnormalities for the prognosis of diffuse large B-cell lymphoma. Chin J Med Genet. 2014;31(5):628-31.

11. Pedersen MO, Gang AO, Brown P, et al. Real world data on young patients with high-risk diffuse large B-cell lymphoma treated with R-CHOP or R-CHOEP - MYC, BCL2 and BCL6 as prognostic biomarkers. PLoS One. 2017;12(10):e0186983.

12. Kawamoto K, Miyoshi H, Yoshida N, et al. MYC translocation and/or BCL2 protein expression are associated with poor prognosis in diffuse large B-cell lymphoma. Cancer Sci. 2016;107(6):853-861.

13. Akay OM, Aras BD, Isiksoy S, et al. BCL2, BCL6, IGH, TP53, and MYC protein expression and gene rearrangements as prognostic markers in diffuse large B-cell lymphoma: a study of 44 Turkish patients. Cancer Genet. 2014;207(3):87-93.

14. Ye Q, Xu-Monette ZY, Tzankov A, et al. Prognostic impact of concurrent MYC and BCL6 rearrangements and expression in de novo diffuse large B-cell lymphoma. Oncotarget. 2015;7(3):2401-16.

15. Akyurek N, Uner A, Benekli M, et al. Prognostic significance of MYC, BCL2, and BCL6 rearrangements in patients with diffuse large B-cell lymphoma treated with cyclophosphamide, doxorubicin, vincristine, and prednisone plus rituximab. Cancer.2012;118(17):4173-83.

16. López AB, de Villambrosía SG, Francisco M, et al. Stratifying diffuse large B-cell lymphoma patients treated with chemoimmunotherapy: GCB/non-GCB by immunohistochemistry is still a robust and feasible marker. Oncotarget. 2016;7(14):18036-49.

17. J. Shustik, G. Han, P. Farinha, et al. Correlations between BCL6 rearrangement and outcome in patients with diffuse large B-cell lymphoma treated with CHOP or R-CHOP. Haematologica. 2010;95(1):96-101.

18. Bergman CC, Gaulard P, Leroy K, et al. Immuno-fluorescence in situ hybridization index predicts survival in patients with diffuse large B-cell lymphoma treated with R-CHOP: a GELA study. J Clin Oncol. 2009;27(33):5573-9.

19. Han $Y$, Xue $Y$, Yang $H$, et al. Immunophenotyping and molecular genetic analysis of diffuse large B-cell lymphoma. Chin J Med Genet. 2013;30(2):143-7.

20. Kawasaki C, Ohshima K, Suzumtya J, et al. Rearrangements of bcl-1, bcl-2, bcl-6, and c-myc in diffuse large B-cell lymphomas. Leukemia and Lymphoma. 2001;42(5):1099-106.

21. Niitsu N, Okamoto $M$, Nakamura N, et al. Prognostic impact of chromosomal alteration of 3q27 on nodal B-cell lymphoma: correlation with histology, immunophenotype, karyotype, and clinical outcome in 329 consecutive patients. Leukemia Res. 2007;31(9):1191-7.

22. Barrans SL, O'Connor SJM, Evans PAS, et al. Rearrangement of the BCL6 locus at $3 q 27$ is an independent poor prognostic factor in nodal diffuse large B-celllymphoma. Brit J Haematol. 2002;117(2):322-32.

23. Jerkeman M, Cavallin-Stahl PAE, Torlakovic E, et al. Prognostic implications of BCL6 rearrangement in uniformly treated patients with diffuse large B-cell lymphoma a Nordic Lymphoma Group study. Int J Oncol. 2002;20(1):161-5.

24. Akasaka $T$, Ueda $C$, Kurata $M$, et al. Nonimmunoglobulin (non-Ig)/BCL6 gene fusion in diffuse large B-cell lymphoma results in worse prognosis than Ig/BCL6. Blood. 2000;96(8):2907-9.

25. Pescarmona E, de Sanctis V, Pistilli A, et al. Pathogenetic and clinical implications of $\mathrm{Bcl}-6$ and $\mathrm{Bcl}-2$ gene configuration in nodal diffuse large B-cell lymphoma. J Pathol. 1997;183(3):281-6.

26. Vitolo U, Gaidano G, Botto B, et al. Rearrangements of bcl-6, bcl-2, c-myc and $6 \mathrm{q}$ deletion in B-diffuse large-cell lymphoma: Clinical relevance in 71 patients. Ann Oncol. 1998;9(1):55-61.

27. Liang X, Wanf J, Bai W, et al. Expression of CD68, cyclin D1 and rearrangement of bcl-6 gene are adverse prognostic factors in diffuse large B-cell lymphoma. Chin J Pathol. 2015;44(8):559-64.

28. Kramer MHH, Hermans J, Wijburg E, et al. Clinical Relevance of BCL2, BCL6, and MYC Rearrangements in Diffuse Large B-Cell Lymphoma. Blood. 1998;92(3):3152-62.

29. Clipson A, Barrans S, Zeng N, et al. The prognosis of MYC translocation positive diffuse large B-cell lymphoma depends on the second hit. J Pathol Clin Res. 2015; 1(3):125-133.

30. Baron BW, Nuciforat G, Mccabe $N$, et al. Identification of the gene associated with the recurring chromosomal translocations 
$\mathrm{t}(3 ; 14)(\mathrm{q} 27 ; \mathrm{q} 32)$ and $\mathrm{t}(3 ; 22)(\mathrm{q} 27 ; \mathrm{ql1})$ in B-cell lymphomas. Proc Natl Acad Sci. 1993;90(11):5262-6.30.

31. Kerckaer JP, Deweindt C, Tilly $\mathrm{H}$, et al. LAZ3, a novel zinc-finger encoding gene, is disrupted by recurring chromosome 3q27 translocations in human lymphomas. Nat Genet. 1993;55(1):66-70.

32. Pfreundschuh M, Ho AD, Stahl EC, et al. Prognostic significance of maximum tumour (bulk) diameter in young patients with good-prognosis diffuse large-B-cell lymphoma treated with CHOP-like chemotherapy with or without rituximab: an exploratory analysis of the MabThera International Trial Group (MInT) study. Lancet Oncol. 2008;9(5):435-44. 